\title{
Hydrogen and Methane Production from Co-digestion of Food Waste and Chicken Manure
}

\author{
Mohd Faiz Mat Saad",2, NorÁini Abdul Rahman'*, \\ Mohd Zulkhairi Mohd Yusoff ${ }^{1,3}$ \\ ${ }^{1}$ Department of Bioprocess Technology, Faculty of Biotechnology and Biomolecular Sciences, \\ Universiti Putra Malaysia, Selangor, Malaysia \\ ${ }^{2}$ Institute of Systems Biology (INBIOSIS), Universiti Kebangsaan Malaysia, Selangor, Malaysia \\ ${ }^{3}$ Laboratory of Biopolymer and Derivatives, Institute of Tropical Forestry and Forest Product (INTROP), \\ Universiti Putra Malaysia, Selangor, Malaysia
}

Received: 17 September 2017

Accepted: 20 January 2018

\begin{abstract}
The production of renewable energy from agro-food waste possesses a lot of advantages over conventional methods. This study aimed at enhancing the hydrogen and methane production from co-digestion of food waste and chicken manure by adding different inoculums: aeration tank sludge (ATS), return activated sludge (RAS) and palm oil mill effluent sludge (POME). One-stage anaerobic fermentation for hydrogen and methane production was carried out in a $150 \mathrm{~mL}$ serum bottle at $35^{\circ} \mathrm{C}$ with initial $\mathrm{pH}$ of 7 . The effects of different combination ratios (food waste and chicken manure) were also examined. The microbial community was determined using next-generation sequencing (NGS) of $16 \mathrm{~S}$ ribosomal RNA technique. Based on the results, the co-digestion of food waste, chicken manure using a combination ratio of 50:50 (v/v) with RAS without heat treatment gave the highest biogas yield at $120.97 \mathrm{NmL} / \mathrm{g}$ COD. The highest percentages of hydrogen and methane produced were $53.35 \%$ and $52.85 \%$, respectively. Clostridium sp. was detected in the biohydrogen production phase with methanogens responsible for biomethane production. Thus, the heat treatment of inoculums was seen as unsuitable for producing biomethane as it inhibits methanogens.
\end{abstract}

Keywords: Co-digestion, hydrogen, methane, chicken manure, food waste, sludge

\section{Introduction}

Fossil fuel is the best source of industrial energy. However, fuel is classified as non-renewable energy

*e-mail: nor_aini@upm.edu.my with its source depleting worldwide [1]. Another source of energy is hydrogen, which is known for being clean. A combination of hydrogen and methane as an energy supply may serve as an alternative energy source. To date, the utilisation of waste materials in producing energy is being developed to counter the economic limitations of hydrogen and methane commercialisation. Co-digestion is a process where more than one 
biodegradable waste are anaerobically digested together to improve biotransformation efficiency. The utilisation of agro-food wastes for enhancing the production of hydrogen and methane through anaerobic fermentation is critical to valorise agro-food wastes, reduce environmental pollution and to complement the limited energy supply [2].

Disposal and accumulation of food waste is one of the major problems in industrialised nations, where wastes are simply discarded. A typical disposal method for kitchen waste is landfilling due to its simplicity and low cost [3]. On the other hand, the increase in population has created a huge demand for meat-based raw materials such as chicken and beef. To fulfil this demand, animal farming and food processing activities have been rapidly grown, leading to the increased amounts of waste materials - especially manure from farming activities. This has further contributed to environmental problems such as greenhouse gas emissions, nutrient run-off, eutrophication and odour problems [4]. Thus, the utilisation of food waste and chicken manure as a source of energy may reduce the accumulation of waste materials in the environment and increase the production of energy from renewable sources.

Anaerobic co-digestion of food waste and chicken manure may enhance the stability of the anaerobic process through the carbon-to-nitrogen $(\mathrm{C} / \mathrm{N})$ balance $[5,6]$. Co-digestion may exhibit a more stable biogas production due to improved buffer capacity [7]. Although reports on the increase of biogas production through co-digestion of food waste with other manure are available, studies addressing both hydrogen and methane production from co-digestion of food waste and chicken manure are yet to be discovered.

The aims of this study are as follow: (i) to assess the performance of anaerobic co-digestion of food waste and chicken manure with different inoculums and substrate ratios, (ii) to evaluate biogas production based on different substrate and inoculum ratios and (iii) to determine the microbial community involved during anaerobic digestion of food waste and chicken manure.

\section{Materials and Methods}

\section{Substrate and Inoculum}

Chicken manure was collected at a farm in the Universiti Putra Malaysia (UPM). Food waste (FW) was collected from the cafeteria in the Faculty of Engineering, UPM. The food waste was manually segregated at a ratio of 3:1:1 in proportion of carbohydrate (rice/bread):protein (meat/fish):fibre (vegetables) (Yasin, 2011). The FW was then diluted with tap water at a ratio of 2:3 for grinding purposes using a kitchen blender. Three types of sludge were used as inoculums: aeration tank sludge (ATS), return activated sludge (RAS) and palm oil mill effluent anaerobic treatment sludge
Table 1. Characteristics of food waste (FW) and chicken manure (CM) used throughout the study.

\begin{tabular}{|c|c|c|}
\hline Parameter & $\begin{array}{c}\text { FW } \\
\text { (Control) }\end{array}$ & $\begin{array}{c}\text { CM } \\
\text { (Control) }\end{array}$ \\
\hline $\mathrm{pH}$ & $5.5 \pm 0.3$ & $9.2 \pm 0.3$ \\
\hline $\mathrm{TS}, \mathrm{g} / \mathrm{L}$ & $96 \pm 4$ & $113 \pm 4$ \\
\hline $\mathrm{TSS}, \mathrm{g} / \mathrm{L}$ & $43 \pm 4$ & $86 \pm 4$ \\
\hline $\mathrm{TVS}, \mathrm{g} / \mathrm{L}$ & $39 \pm 3$ & $58 \pm 3$ \\
\hline $\mathrm{VSS}, \mathrm{g} / \mathrm{L}$ & $17 \pm 3$ & $37 \pm 3$ \\
\hline $\mathrm{COD}, \mathrm{g} / \mathrm{L}$ & $120 \pm 2$ & $564 \pm 2$ \\
\hline
\end{tabular}

(POME sludge). ATS and RAS were collected from the sewage treatment plant at Indah Water Konsortium Sdn Bhd, Putrajaya, Malaysia. ATS is a sludge produced after preliminary treatment of sewage, whereas RAS is a sludge produced after the secondary treatment of sewage. RAS is more concentrated than ATS as the biological treatment to remove organic and suspended solids happening in this secondary treatment. POME sludge was collected from the anaerobic treatment pond at Seri Ulu Langat Palm Oil Mill Sdn Bhd in Dengkil, Selangor, Malaysia. All substrates and inoculums were stored in a chiller $\left(4^{\circ} \mathrm{C}\right)$ prior to use. The co-digestion substrate properties of food waste (FW) and chicken manure $(\mathrm{CM})$ used are shown in Table 1. Different sludges as inoculums were added into substrate: ATS, RAS and POME sludge, which were labelled as S1, S2 and $\mathrm{S} 3$, respectively (Table 2).

\section{Batch Fermentation}

Batch fermentation was conducted in a $150 \mathrm{~mL}$ serum bottle with a working volume of $100 \mathrm{~mL}$, with $20 \mathrm{~mL}$ of inoculum and $80 \mathrm{~mL}$ of substrates thoroughly mixed before being added into the serum bottle. Each serum bottle was sparged with nitrogen gas for 5 minutes at $300 \mathrm{~mL} / \mathrm{min}$ to provide anaerobic condition. The bottle was sealed airtight with a rubber stopper and aluminium cap. The gas produced was measured using water replacement technique and stored in a hungate tube. The feasibility study of hydrogen and methane production from food waste and chicken manure was investigated by examining the effects of key operating parameters, which included the ratio of substrate, inoculum and the effects of heat treatment of selected inoculum. Four different ratios of food waste and chicken manure with no addition of inoculums was prepared, which are 60:40, 50:50, 40:60 and $30: 70(\mathrm{v} / \mathrm{v})$ in proportion of FW:CM. To evaluate the effects of different inoculums on hydrogen and methane fermentation, the selected ratio of substrate producing the highest gas volume was tested with three different inoculums (ATS, RAS and POME). The effects of heat pretreatment of inoculum were determined by selecting the highest biogas produced from the previous step. 
Table 2. Characteristics of substrate (food waste and chicken manure) with different inoculums.

\begin{tabular}{|c|c|c|c|c|}
\hline Parameter & FW+CM & S1 (FW:CM:ATS) & S2 (FW:CM:RAS) & S3 (FW:CM:POME) \\
\hline $\mathrm{pH}$ & $6.7 \pm 0.7$ & $7.1 \pm 0.3$ & $7.3 \pm 0.4$ & $6.7 \pm 0.3$ \\
\hline TS, g/L & $1260 \pm 3$ & $900 \pm 5$ & $1200 \pm 5$ & $1900 \pm 3$ \\
\hline TSS, g/L & $1000 \pm 3$ & $710 \pm 5$ & $1100 \pm 4$ & $680 \pm 4$ \\
\hline TVS, g/L & $850 \pm 4$ & $680 \pm 3$ & $940 \pm 3$ & $650 \pm 4$ \\
\hline VSS, g/L & $740 \pm 4$ & $660 \pm 4$ & $870 \pm 4$ & $560 \pm 4$ \\
\hline COD, g/L & $206 \pm 2$ & $237 \pm 4$ & $186 \pm 2$ & $240 \pm 4$ \\
\hline
\end{tabular}

The inoculums were preheated at $80^{\circ} \mathrm{C}$ for 20 minutes in a water bath prior to fermentation. The initial $\mathrm{pH}$ for all fermentation was adjusted to $\mathrm{pH} 7$.

\section{Gas Analysis}

The biogas generated from the batch fermentation was collected by water displacement method and stored in a Hungate tube. The normalised volume $(\mathrm{NmL})$ represents the biogas production at the indicated standard temperature and pressure (stp) [8]. The biogas samples were then examined by gas chromatography (Agilent- 6890N) with a thermal conductivity detector (TCD) and a capillary column of Carboxen-1010 PLOT for biogas measurement. The detected gases include hydrogen, oxygen, methane and carbon dioxide. The temperature of the injection port, column and TCD were $200^{\circ} \mathrm{C}, 230^{\circ} \mathrm{C}$ and $230^{\circ} \mathrm{C}$, respectively. Argon gas was used as a carrier gas with a flow rate of $3 \mathrm{~mL} / \mathrm{min}$.

\section{Analytical Methods}

The total chemical oxygen demand (COD), $\mathrm{pH}$, total solid (TS), total suspended solid (TSS), volatile suspended solid (VSS) and total volatile solid (TVS) were measured according to the standard methods [9]. Organic acids were calculated by HPLC (Shimadzu LC-10AS with UV-VIS detector SPD-10A) with $4 \mathrm{mM}$ sulphuric acid as the mobile phase at a flow rate of $0.6 \mathrm{~mL} / \mathrm{min}$. A modified Gompertz equation was used to analyse biogas production in batch mode based on Equation 1, where B is the cumulative biogas production $(\mathrm{mL}), \mathrm{P}$ is the biogas production potential $(\mathrm{mL}), \mathrm{Rm}$ is the maximum hydrogen production rate $\left(\mathrm{mLh}^{-1}\right), \lambda$ is lag phase time (h), $t$ is fermentation time (h) and $e$ is 2.718 [10]:

$$
B=P \cdot \exp \left\{-\exp \left[\frac{R m \cdot e}{P}(\lambda-t)+1\right]\right\}
$$

\section{Microbial Characterisation}

Microbial characterisation was carried out to assess the phyla of available microorganisms present in the samples of heat-treated and non-treated inoculums. To compare the microorganisms in the mixture, samples used for this analysis were collected at the start (day 0) and at the end of fermentation (day 10). The selected samples were sent to First BASE Laboratories Sdn Bhd for $16 \mathrm{~S}$ ribosomal RNA (rRNA) analysis. The samples were then sequenced using 454 Sequencin on the Genome Sequence FLX System.

\section{Results and Discussion}

\section{Effects of Substrate Ratio}

The total mean biogas production and corresponding $\mathrm{CH} 4$ and $\mathrm{H} 2$ contents for the mixture ratios are shown in Fig. 1. Fig. 1a) demonstrates that the total gas production was gradually increased in the fermentation process for all ratios tested. Most of the total biogas production occurred at the initial stage of the fermentation process. After 10 days of fermentation, the total biogas production of 40:60, 50:50, 60:40 and 70:30 of FW:CM were $1137.5,1183,1082.9$ and $906.36 \mathrm{NmL}$, respectively. Generally, as the proportion of CM decreases in the mixture, biogas production decreased. This finding is in agreement with a study reporting that higher biogas was produced as the added manure increased [11]. The mixture ratio of 50:50 gave the highest total biogas production compared to other ratios.

The ratio of 40:60 of $\mathrm{FW}: \mathrm{CM}$ gave a total volume of $1137.5 \mathrm{NmL}$ biogas production. This was due to the concentration of free ammonia presents in the mixture that might inhibit the methanogenic microbes [12]. It was found that increased proportion of food waste to $50 \%$ had improved biogas production [7]. FW represents a huge number of carbon and some amount of nitrogen loading in the fermenter, while CM represents the mixed culture and nitrogen source. However, a high FW ratio (70:30) gave a low biogas production $(906.36 \mathrm{NmL}$ ), which might be due to the accumulation of VFA produced during fermentation.

The biogas produced was mainly composed of $\mathrm{H}_{2}$, $\mathrm{CH}_{4}$ and $\mathrm{CO}_{2}$. The contents of $\mathrm{H}_{2}, \mathrm{CH} 4$ and $\mathrm{CO}_{2}$ in biogas varied depending on the stage of fermentation. A high percentage of $\mathrm{H}_{2}$ was detected at the early 
stage of fermentation and gradually decreased after the fourth day of fermentation (Fig. 1b). The highest $\mathrm{H}_{2}$ production was $38.26 \%$ on the fourth day at a ratio of 50:50 (FW:CM). In contrast, a low $\mathrm{H} 2$ and high $\mathrm{CH}_{4}$ content were obtained at the end of fermentation. The $\mathrm{CH}_{4}$ content was found to have gradually increased along the fermentation with the decrease of $\mathrm{H}_{2}$ content. The highest $\mathrm{CH} 4$ content was $49.02 \%$ on the $10^{\text {th }}$ day of fermentation at a ratio of $50: 50(\mathrm{FW}: \mathrm{CM})$. It is apparent that $\mathrm{pH}$ value plays an important role in biogas production. Initial $\mathrm{pH}$ was adjusted to
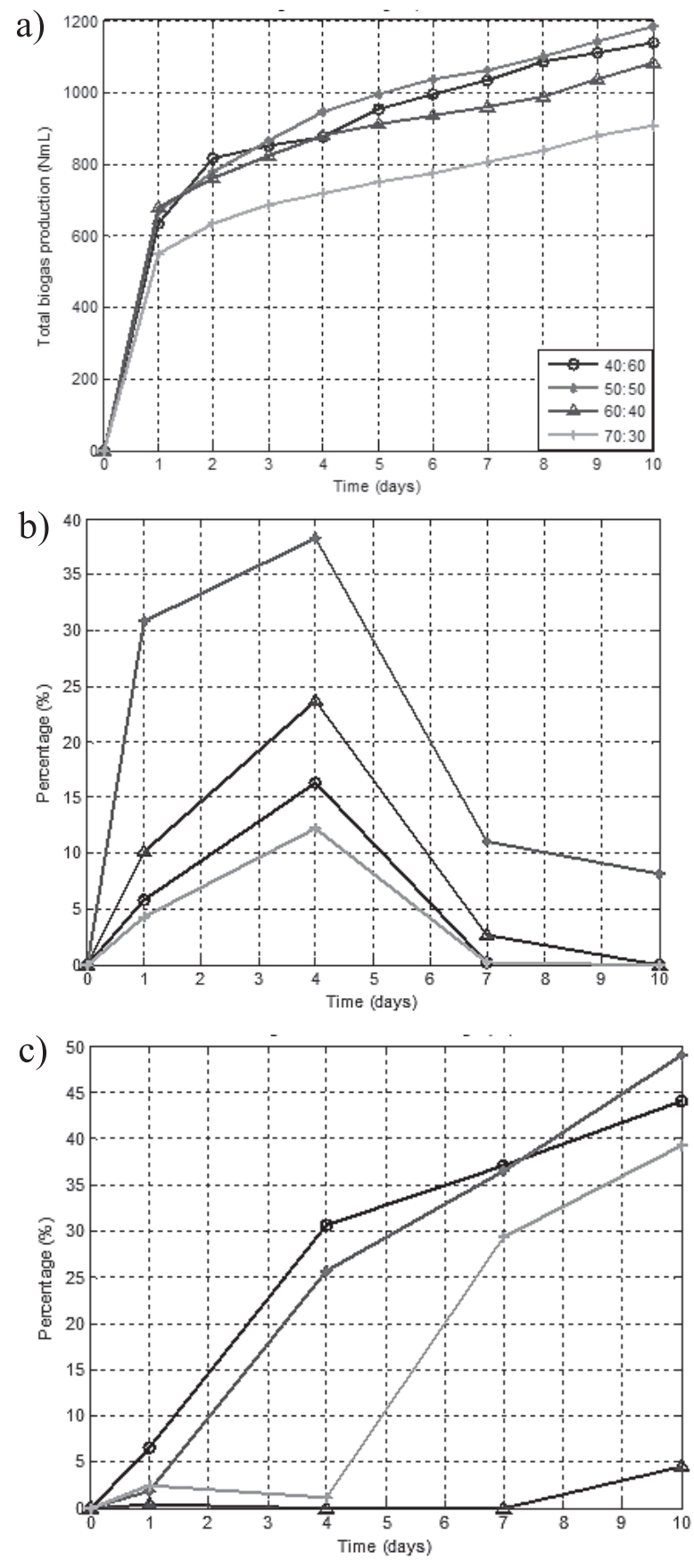

Fig. 1. Total biogas production a), hydrogen concentration b), and methane concentration c) in batch fermentation at different FW and CM ratios.
7.0 since gas production is often the highest when $\mathrm{pH}$ is between 7.0 and 7.2 [13]. Beyond these ranges, the digestion proceeded with less efficiency. If the $\mathrm{pH}$ is reduced to 6 or below, the efficiency drops and acidic conditions occur. The medium then becomes inhibitory to methanogenic microbes, while at $\mathrm{pH} 7.0$ there is a balance in the population of the acidogenic and methanogenic microbes, which helps to convert the acid generated during anaerobic digestion to biogas [14].

$\mathrm{pH}$ drops in the reactor can cause serious volatile fatty acid (VFA) inhibition on the activity of methanogens leading to activity loss of acid-sensitive glycolytic enzymes $[15,16]$. By adjusting the $\mathrm{C} / \mathrm{N}$ ratio, the VFA inhibition on methanogenesis activities in the fermenter can be reduced [17]. Furthermore, low biogas production might be due to the inhibition caused by the fast accumulation of VFA and short biogas accumulation time. High levels of dissociated acid accumulation and $\mathrm{pH}$ drops were caused by the high concentration of VFA, both of which inhibit methanogenic activity and biogas production. It is noteworthy that the VFA detected in all batches was acetic acid, as shown in Fig. 2.

The result showed the presence of acetic acid in the fermenter at the end of fermentation. Acetic acid was dominant in 60:40 and 70:30 ratios of food waste and chicken manure compared to 40:60 and 50:50 ratios, producing a higher biogas production. Acetic acid presented in the fermenter was the main factor that inhibits biogas production. From the metabolic pathway during hydrogen fermentation, the production of acetate and butyrate would be accompanied by hydrogen production [18]. However, the high concentration of acetic acids produced would lower the biogas production. There was no correlation between butyrate and biogas production as the butyrate concentration remained essentially the same for all different substrate ratios.

However, the increase in $\mathrm{CM}$ proportion will not necessarily produce higher biogas production. The ratio of 40:60 of FW:CM gave a total volume of 1137.5 NmL biogas production. This might be due to

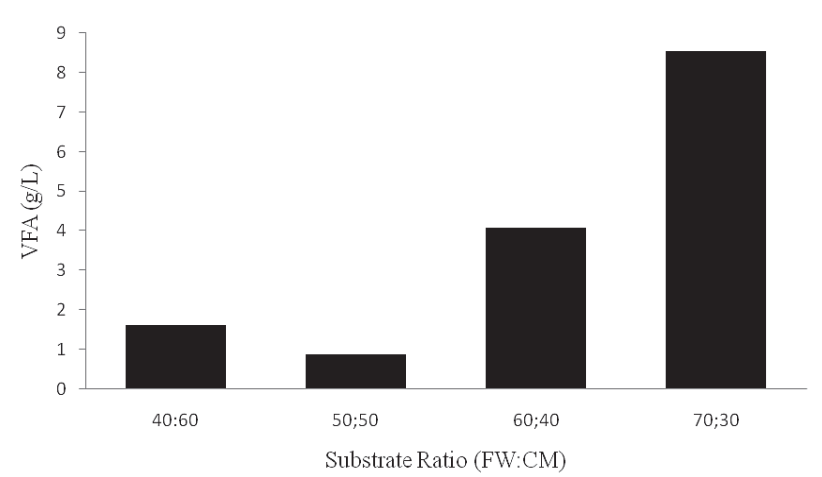

Fig. 2. Concentrations of acetic acids produced in anaerobic digestion for different substrate ratios of food waste and chicken manure at day 10 . 
the concentrations of free ammonia present in the mixture inhibiting the methanogenic microbes [19]. Meanwhile, the increased proportion of food waste to $50 \%$ improved biogas production [20]. Generally, FW represents a huge amount of carbon and some amount of nitrogen loading in the fermenter, while CM represents mixed culture and nitrogen source. However, high FW ratio (70:30) gave lower biogas production (906.36 $\mathrm{NmL}$ ) due to the accumulation of VFA produced during fermentation.

\section{Effects of Different Inoculums}

Several types of inoculums have been used for biogas fermentation in previous studies such as anaerobic digested sludge [21, 22, 23], agricultural soil $[24,25]$ and sludge compost $[24,26]$. In this study, three types of inoculums were tested. The gas produced from the fermentation were then compared with control (FW:CM) without any addition of inoculums. The best ratio of $\mathrm{FW}: \mathrm{CM}$, which is 50:50, was used in this test. Fig. 3 illustrates a total mean of biogas production and the corresponding $\mathrm{CH}_{4}$ and $\mathrm{H}_{2}$ contents for different inoculums. At the end of fermentation, the total biogas yield of FW:CM (control), S1, S2 and S3 were 90.05, $82.75,120.97$ and $67.48 \mathrm{NmL} / \mathrm{g}$ COD, respectively. Batch fermentation of a biogas production strongly depends on inoculums used; however, the addition of inoculums does not necessarily give higher biogas production since the production of biogas depends on the bacterial activity in the fermenter. The highest biogas yield was obtained from S2 with $120.97 \mathrm{NmL} / \mathrm{g}$ COD. The addition of inoculums in the system can enhance hydrogen production due to the existence of bacteria in inoculums [27]. Bacteria from Clostridium species has an adverse effect on anaerobic fermentation and accelerates the enrichment of hydrogenase.

The highest percentage of $\mathrm{H}_{2}$ was produced on the first day of fermentation $(82.7 \%)$. The $\mathrm{CH}_{4}$ content was gradually increased along the fermentation with the decrease in $\mathrm{H}_{2}$ content. This is due to the methanogenesis step that happened in the last phase of anaerobic digestion where methanogens utilize $\mathrm{H}_{2}$ and $\mathrm{CO}_{2}$ to produce methane. The highest percentage of $\mathrm{CH}_{4}$ was obtained on the last day of fermentation by $50.48 \%$. The highest percentage was obtained from the similar combination of FW:CM inoculated with RAS (S2). By adding inoculums, a slightly higher percentage of $\mathrm{H}_{2}$ and $\mathrm{CH}_{4}$ gas in comparison to the control was observed.

Anaerobic digestion of food waste and chicken manure by adding inoculums has resulted in a reduction of biomass and solid content [28]. The reduction of solids indicated the efficiency of anaerobic treatment to degrade solids in the system. Table 3 displays that the solid has greatly reduced. Anaerobic fermentation with S2 (RAS) as inoculums gave the highest reduction efficiency for both TSS and VSS by $70.91 \%$ and $84.62 \%$, respectively. This indicated that the inoculum had degraded more solids in the system, thus producing
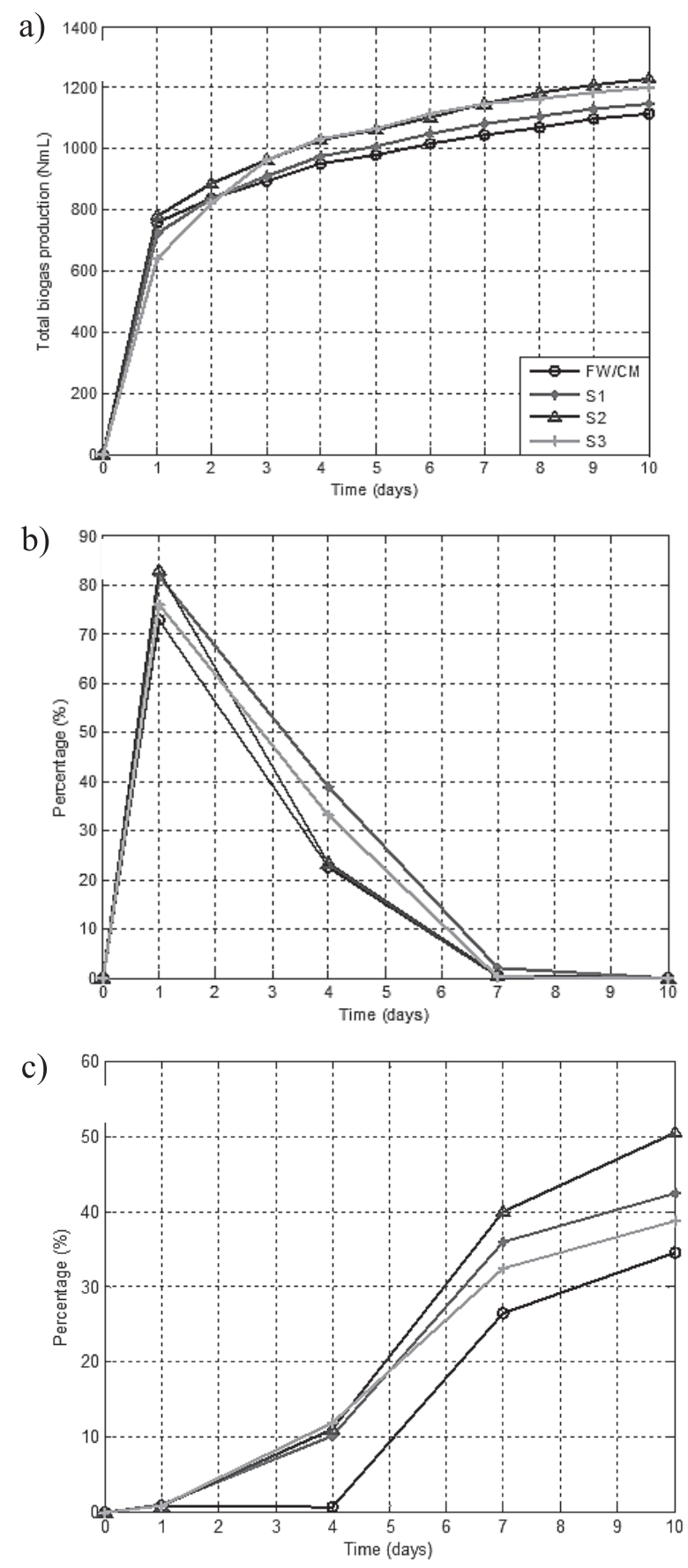

Fig. 3. Total biogas production a), hydrogen percentage b), and methane percentage c) in batch fermentation of FW and $\mathrm{CM}$ using different inoculums.

a higher volume of biogas. COD of the substrate was also greatly reduced in the range of $54-75 \%$ for all fermentations (Table 3 ).

\section{Effects of Heat Treatment of Inoculums}

Fig. 4a) shows the percentage of hydrogen and methane production upon control, untreated inoculums and heat-treated inoculums. Inoculums with heat treatment produced the highest percentage of $\mathrm{H}_{2}$ by $58.37 \%$ on the first day of fermentation, followed by 

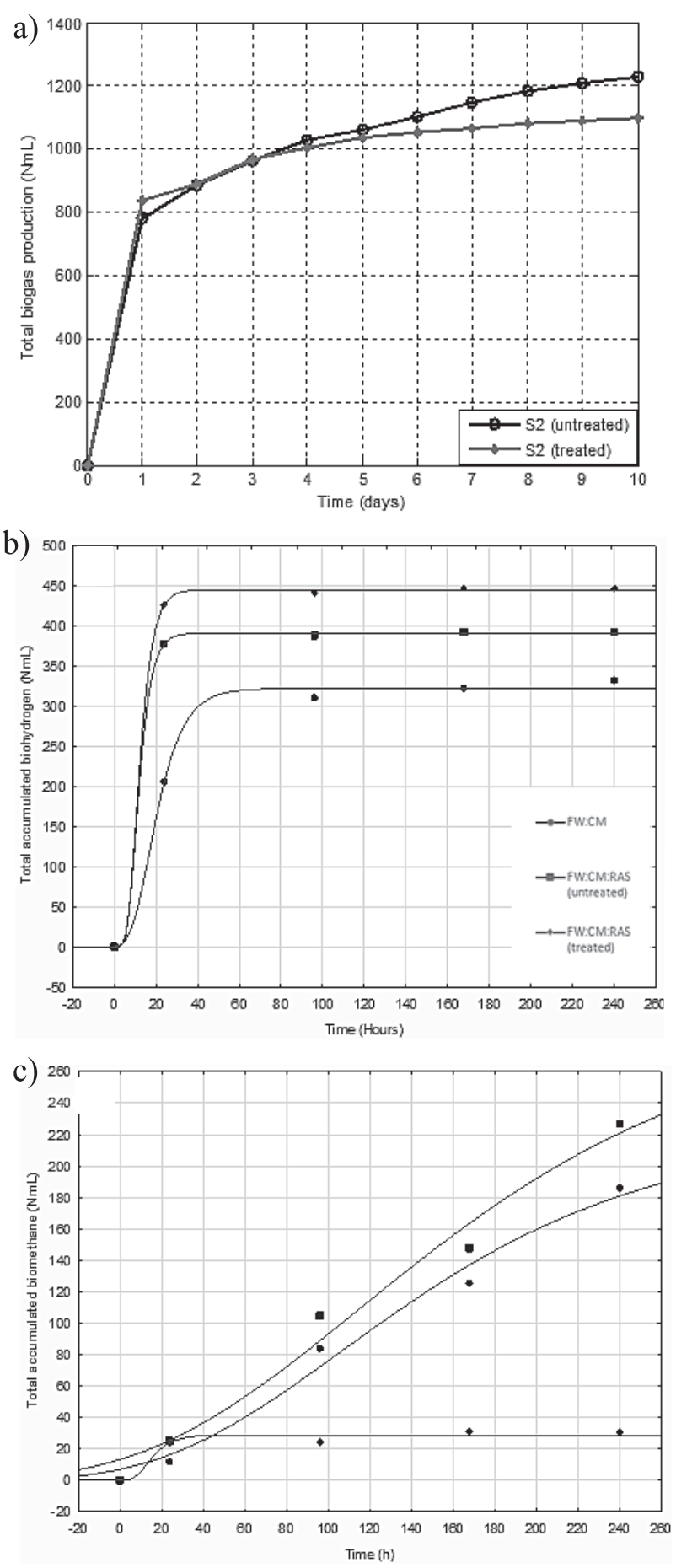

Fig. 4. Anaerobic fermentation of FW and CM for hydrogen and methane in batch test using treated and untreated inoculums. untreated inoculums by $53.35 \%$ of $\mathrm{H}_{2}$. Heat-treated inoculums showed slightly higher $\mathrm{H}_{2}$ percentage compared to untreated inoculums. It is obvious that the addition of inoculums to the system has accelerated the $\mathrm{H}_{2}$ production. Heat treatment at $80^{\circ} \mathrm{C}$ for 20 minutes is generally regarded as an efficient method to suppress methanogenic microbes and enrich hydrogen-producing spore forming bacteria such as Clostridium species [29].

The highest percentage of $\mathrm{CH} 4$ was obtained from untreated inoculums at $52.85 \%$ on the last day of fermentation. Very low percentages of $\mathrm{CH}_{4}$ were obtained throughout the experiment for treated inoculum. Heat treatment of inoculums had eliminated the methanogenesis stage of anaerobic digestion in the mixed culture by suppressing methanogens from inoculums. Heat treatment did not affect much of the $\mathrm{H}_{2}$ production, but strongly inhibited the $\mathrm{CH}_{4}$ percentage. These suggested that the heat treatment method upon inoculums is not suitable for methane production.

Table 4 presents the statistical analysis of biohydrogen and biomethane production of food waste and chicken manure with treated and untreated inoculums from the modified Gompertz equation. The normalised volume $(\mathrm{NmL})$ represents the biogas production at indicated standard temperature and pressure (stp) [8]. For biohydrogen, treated RAS as inoculums showed the highest biohydrogen production potential of $445.09 \mathrm{NmL}$ and rate of $38.19 \mathrm{NmL} / \mathrm{h}$ compared to untreated inoculums. These were in contrast with untreated inoculum, which showed the highest biomethane production of $294.83 \mathrm{NmL}$ at a rate of $1.07 \mathrm{NmL} / \mathrm{h}$ over treated inoculums. Biohydrogen production potential $(\mathrm{P})$ for treated inoculums was observed significantly different to untreated inoculums. Similarly, biomethane production potential (P) for untreated inoculums was also significantly different from treated inoculums. The rate of biogas production mainly depends on bacterial activities. Table 4 shows that the rate of biohydrogen production is higher in treated inoculums compared to that of untreated inoculums. For biomethane production, treated inoculums showed a high rate of $1.66 \mathrm{NmL} / \mathrm{h}$.

Treated inoculums produced higher biohydrogen potential due to the inhibition of hydrogen-consuming microbes during the heat treatment of inoculums. However, treated inoculum gave a low biomethane production since methanogens were also inhibited

Table 3. Reduction efficiency of solids and COD for anaerobic digestion of FW and CM with different inoculums.

\begin{tabular}{|c|c|c|c|c|}
\hline Parameter $(\%)$ & FW/CM & S1 (FW:CM:ATS) & S2 (FW:CM:RAS) & S3 (FW:CM:POME) \\
\hline TS & 72 & 78.33 & 62.22 & 72.63 \\
\hline TSS & 56 & 62.01 & 25.35 & 58.82 \\
\hline TVS & 47.62 & 46.81 & 18.96 & 50.77 \\
\hline VSS & 27.27 & 39.05 & 13.54 & 50 \\
\hline COD & 60.19 & 58.65 & 54.6 & 74.17 \\
\hline
\end{tabular}


Table 4. Performance of hydrogen and methane production of food waste and chicken manure with treated and untreated inoculums.

\begin{tabular}{|c|c|c|c|c|}
\hline \multirow{2}{*}{ Parameters } & \multicolumn{2}{|c|}{ Biohydrogen } & \multicolumn{2}{c|}{ Biomethane } \\
\cline { 2 - 5 } & $\mathrm{S} 2$ & $\mathrm{~S} 2$ & S2 & (untreated) \\
\cline { 2 - 5 } & (untreated) & (treated) & 294.83 & 28.84 \\
\hline $\mathrm{P}(\mathrm{NmL})$ & 391 & 445.09 & 1.07 & 1.66 \\
\hline Rate $(\mathrm{NmL} / \mathrm{h})$ & 35.02 & 38.19 & 13.31 & 6.8 \\
\hline$\lambda(\mathrm{h})$ & 6.11 & 6.24 & 52.85 & 6.26 \\
\hline
\end{tabular}

during the heat treatment. These results indicated that treated inoculum was unsuitable to be used as inoculums for producing biomethane. Compared to untreated inoculums, although it gave a lower biohydrogen potential, high biomethane potential presented its suitability for the production of biohydrogen and biomethane. This result was supported with a shorter lag-phase $(\lambda)$ for biomethane production of untreated inoculums when compared to treated inoculums.

Table 5 demonstrates the comparison of biogas yield of different types of feedstock. Biogas production from food waste has been widely carried out in many studies using POME sludge, sewage sludge and manure in batch operation mode. This implies that the presence of indigenous microorganisms and high carbon content in food waste make it suitable as a feedstock for biogas production under non-sterile conditions.

Several studies have been conducted for the codigestion of food waste with other substrates for producing biohydrogen and biomethane. In this study, the co-digestion of food waste and chicken manure added with the selected inoculum gave a yield of 120.97 NmL/g COD. The results obtained showed that they are comparable with other studies. Previous studies from other researchers proved that the co-digestion of different waste can increase the biogas production compared to single digestion fermentation. This is due to the better $\mathrm{C} / \mathrm{N}$ ratio, better buffering capacity, more diverse nutrient content or dilution of inhibiting compounds and a more biologically stable process [30].

\section{Bacterial Community Diversity}

The heat-treated and non-treated samples of inoculum combined with the substrate were analysed using MEGAN5 software to process the 16S database alignments in producing the taxonomical classification of microbes identified in the samples. MEGAN5 parsed the alignment files, filtered it based on significant threshold and then placed the sequence in the correct taxonomical branch. Figs 5 and 6 present the taxonomical classification of microbes for both treated and untreated samples.

The diversity of microbes present in the untreated sample is higher than that of heat-treated samples. Heat treatment of samples is an efficient method to inhibit the undesired microbes. One previous study had proved that there is a high presence of methanogens in the raw POME sludge samples before it was subjected to heat treatment [31]. The raw POME sludge was then subjected to heat treatment to eliminate methanogens that can inhibit biohydrogen production [28]. The same pattern of observation can be seen from this study. The diversity of microbes was higher in the heat-treated sample compared to untreated samples.

It is well known that Clostridium genus is responsible for a high biohydrogen production at the early stage of fermentation [32]. The bacteria in the Clostridium family are rod-shaped and endospore forming, which are responsible for the high yield of biohydrogen production under strict anaerobic conditions [33]. The presence of Clostridium butyricum and Clostridium perfringens

Table 5. Comparison of biogas yield of different types of feedstock.

\begin{tabular}{|c|c|c|c|c|c|c|}
\hline Feedstock & $\begin{array}{c}\text { Temperature } \\
\left({ }^{\circ} \mathrm{C}\right)\end{array}$ & $\begin{array}{c}\text { Initial } \\
\mathrm{pH}\end{array}$ & $\begin{array}{l}\text { Biogas yields } \\
(\mathrm{mL} / \mathrm{gCOD})\end{array}$ & $\begin{array}{l}\mathrm{H}_{2} \\
(\%)\end{array}$ & $\begin{array}{l}\mathrm{CH}_{4} \\
(\%)\end{array}$ & References \\
\hline Food waste and POME sludge & 55.7 & 7.5 & 120 & 43 & 72 & Ismail et al. (2010) \\
\hline Food waste and sewage sludge & 35 & 7 & 112 & 63 & ND & Zhu et al. (2008) \\
\hline Food waste and sludge & 30 & ND & 102.63 & 55 & ND & Sreela-or et al. (2011) \\
\hline Sonicated food waste & 37 & 5.5 & 97 & 66 & ND & Elbeshbishy et al. (2011) \\
\hline $\begin{array}{l}\text { Treatment chicken manure: } \\
\text { Chicken manure }\end{array}$ & ND & 8 & 157 & ND & 58 & Abouelenien et al.,(2010) \\
\hline Food waste and chicken manure & 35 & 7 & 120.97 & 53.35 & 52.85 & This study \\
\hline
\end{tabular}




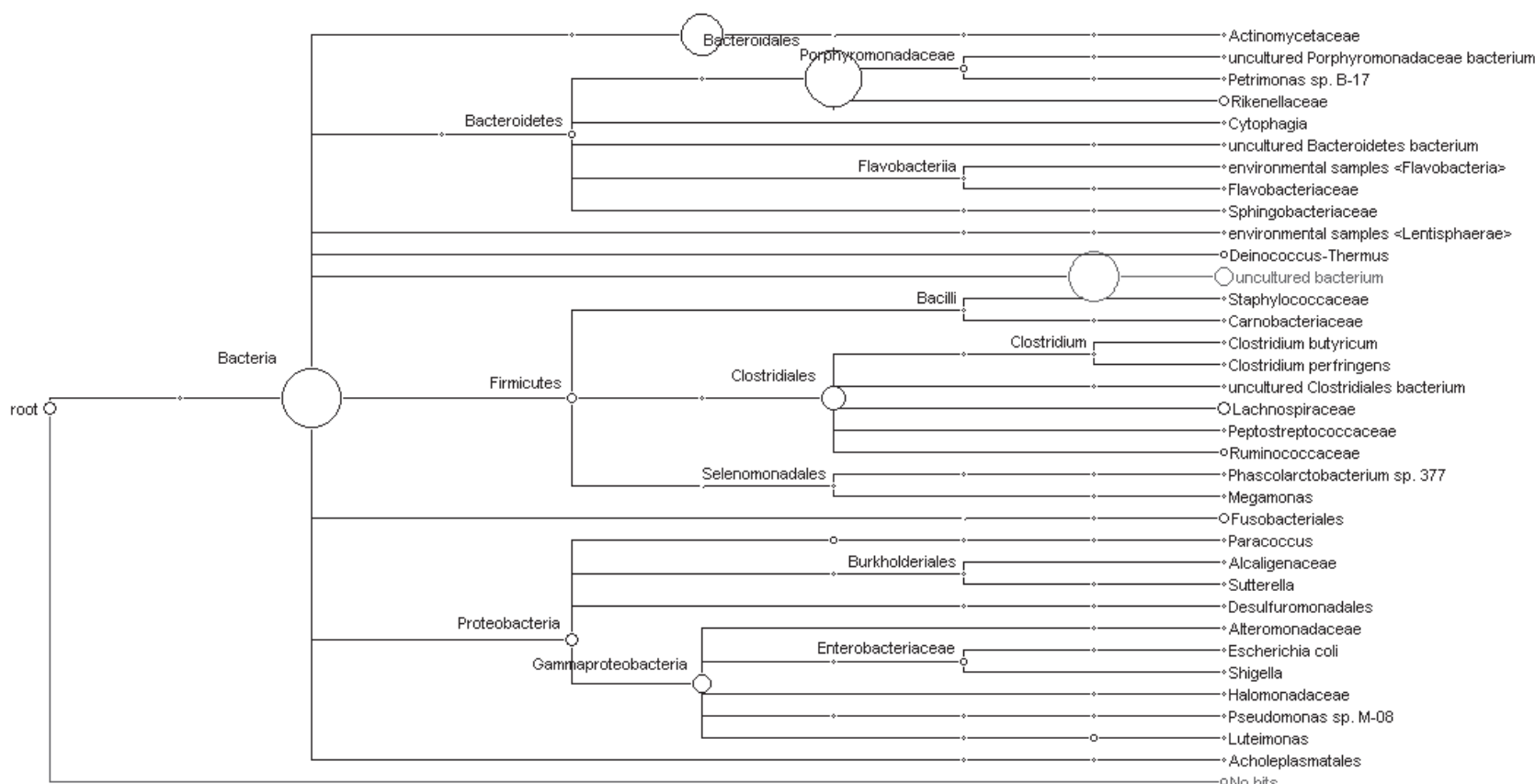

Fig. 5. Taxonomical classification of microbes identified in the combination of food waste, chicken manure and heat-treated inoculums.

in both treated and untreated samples proved the dominance of hydrogen-producing bacteria in the samples of food waste and chicken manure. Clostridium sp. contains hydrogenase genes that generate hydrogen through acidogenesis and acetogenesis stages during anaerobic degradation [34].

Methanogens on the other hand are the members of Archea domain [31]. Methanogens comes in two shapes, which are coccus with circle and rod shapes. Most of them live in close association with certain bacteria by consuming compounds produced by the bacteria [32]. Methanogens can be considered as hydrogenconsuming organisms as they consume hydrogen and organic acids during anaerobic digestion for biomethane production [33]. The diversity of the microbes in the heat-treated samples was lower compared to non-treated

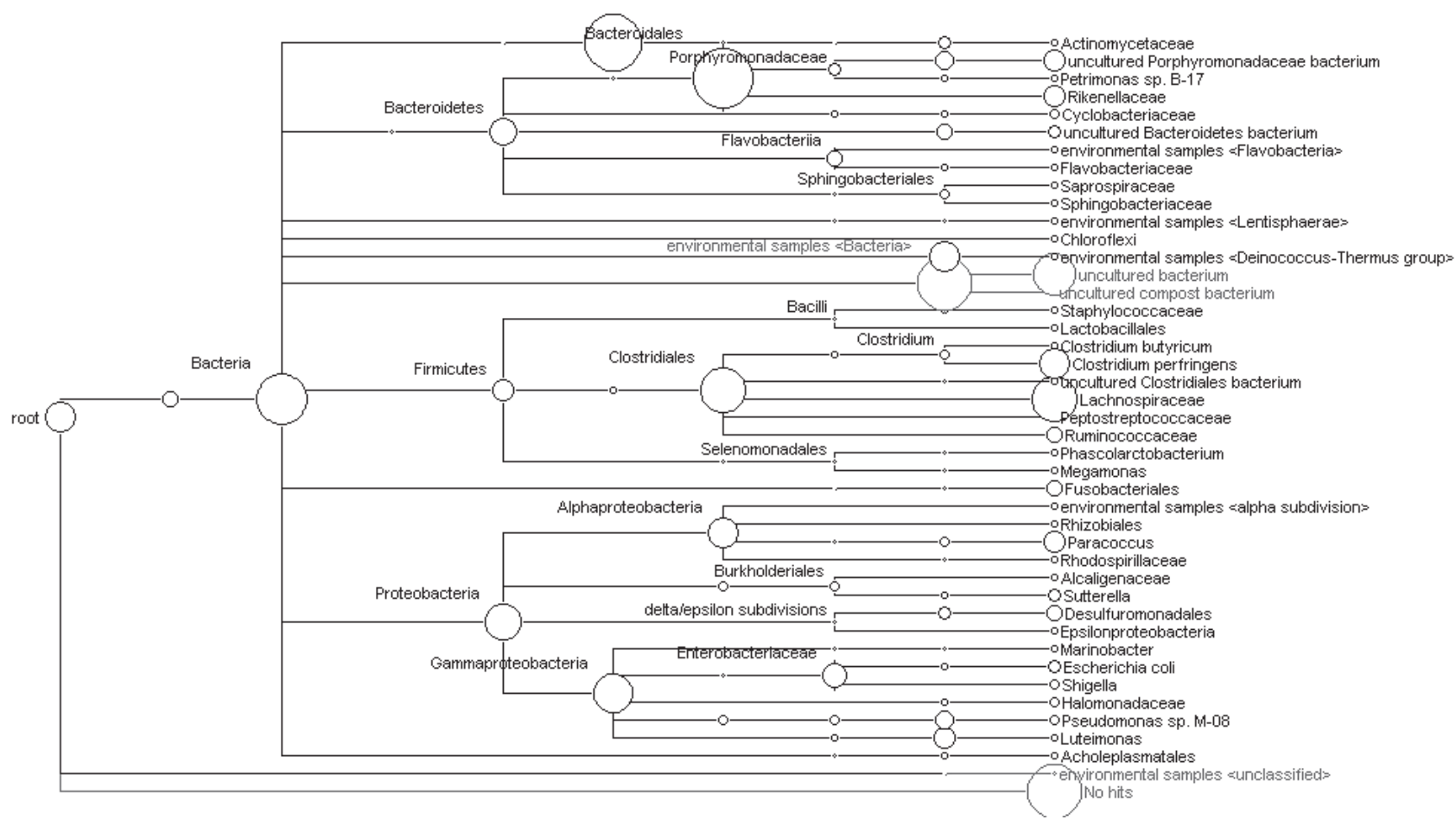

Fig. 6. Taxonomical classification of microbes identified in the combination of food waste, chicken manure and non-treated inoculums. 
samples. The heat-treated samples gave a low methane percentage due to the inhibition of methanogens at high temperature. Conversely, untreated samples gave a high methane percentage due to active methanogens that consume hydrogen and organic acid to produce biomethane gas.

\section{Conclusions}

This study has showed that the production of hydrogen and methane was enhanced by optimising the substrate ratio added with selected inoculums without any pretreatment. The analysis of gas production indicated that the mixing ratio and inoculum has greatly affected the $\mathrm{H}_{2}$ and $\mathrm{CH}_{4}$ production from food waste and chicken manure, whereas heat treatment of inoculum did not enhance $\mathrm{CH}_{4}$ production. The best $\mathrm{H}_{2}$ and $\mathrm{CH}_{4}$ production was obtained from a combination ratio of 50:50 of FW:CM with the addition of untreated return activated sludge as inoculums, which gave $53.35 \%$ and $52.85 \%$ of $\mathrm{H}_{2}$ and $\mathrm{CH}_{4}$, respectively, with a yield of $120.97 \mathrm{NmL} / \mathrm{g}$ COD. The results showed that the combination of food waste, chicken manure and heat-treated samples is only suitable for biohydrogen production since metanogens were inhibited after the heat treatment. The taxonomical classification of both treated and untreated samples supported heat treatment only being suitable for biohydrogen production and not biomethane production.

\section{Acknowledgements}

The authors would like to thank the Faculty of Biotechnology and Biomolecular Sciences, Universiti Putra Malaysia for facilities provided while conducting this project.

\section{Conflict of Interest}

The authors declare no conflict of interest.

\section{References}

1. AZBAR N., LEVIN D.B. State of the Art and Progress in Production of Biohydrogen. Bentham Science Publishers, 2012.

2. HIDALGO D., MARTIN-MARROQUIN J.M., NEITO P. Anaerobic Co-digestion of Agro-Food Waste Mixture in a Fed-Batch Basis. Environmental Technology, 37 (20), 2016.

3. KANAT G. Municipal solid-waste management in Istanbul. Waste Management (New York, N.Y.), 30 (8-9), 2010.

4. LUOSTARINEN S., LOGRÉN J., GRÖNROOS J., LEHTONEN H., PAAVOLA T. Lannan kestävä hyödyntäminen. MTT Raportti, 21, 2011.
5. EL-MASHAD H.M., ZHANG R. Biogas production from co-digestion of dairy manure and food waste. Bioresource Technology, 101 (11), 2010.

6. MSHANDETE A., KIVAISI A., RUBINDAMAYUGI M., MATTIASSON B. Anaerobic batch co-digestion of sisal pulp and fish wastes. Bioresource Technology, 95 (1), 2004.

7. NAYONO S.E., GALLERT C., WINTER J. Co-digestion of press water and food waste in a biowaste digester for improvement of biogas production. Bioresource Technology, 101 (18), 2010.

8. YASIN N.H. M. Optimisation of Physical Parameters and Microbial Community Analysis of Bio-Hydrogen Production from Food Waste, 2011.

9. APHA. Standard Methods for the Examination of Water \& Wastewater. American Public Health Association, 2005.

10. ZHANG M.-L., FAN Y.-T., XING Y., PAN C.-M., ZHANG G.-S.LAY J.-J. Enhanced biohydrogen production from cornstalk wastes with acidification pretreatment by mixed anaerobic cultures. Biomass and Bioenergy, 31(4), 2007.

11. YUSOF T.R.T. Methane Production from Co-Digestion of Poultry Manure and Food Waste, 2014.

12. ABOUELENIEN F., NAMBA Y., KOSSEVA M.R., NISHIO N., NAKASHIMADA Y. Enhancement of methane production from co-digestion of chicken manure with agricultural wastes. Bioresource Technology, 159, 2014.

13. IORTYER H.A., IBRAHIM J.S., KWAGHGER A. Effect of Mixing Ratio of Cattle and Piggery Dung on Biogas Generation. International Journal of Environment and Bioenergy 1 (3), 2012.

14. FALAH F.B., QASAIMEH A., QASAIMEH M.R.A. Biogas Production Enhancement from Mixed Animal Wastes at Mesophilic Anaerobic Digestion, 2015.

15. BOUALLAGUI H., TOUHAMI Y., BEN CHEIKH R., HAMDI M. Bioreactor performance in anaerobic digestion of fruit and vegetable wastes. Process Biochemistry, 40 (3-4), 2005.

16. MISI S.N., FORSTER C.F. Batch co-digestion of multicomponent agro-wastes. Bioresource Technology, 80 (1), 2001.

17. ASTALS S., ARISO M., GALÍ A., MATA-ALVAREZ J. Co-digestion of pig manure and glycerine: Experimental and modelling study. Journal of Environmental Management, 92 (4), 2011.

18. LIU X., LI R., JI M., HAN L. Hydrogen and methane production by co-digestion of waste activated sludge and food waste in the two-stage fermentation process: Substrate conversion and energy yield. Bioresource Technology, 146, 2013.

19. ABOUELENIEN F., FUJIWARA W., NAMBA Y., KOSSEVA M., NISHIO N., NAKASHIMADA Y. Improved methane fermentation of chicken manure via ammonia removal by biogas recycle. Bioresource Technology, 101 (16), 2010.

20. WAN S., SUN L., SUN J., LUO W. Biogas production and microbial community change during the Co-digestion of food waste with chinese silver grass in a singlestage anaerobic reactor. Biotechnology and Bioprocess Engineering, 18 (5), 2013.

21. CHEN CHIU-YUE LIN, MIN-CHENG LIN C.-C. Acid - base enrichment enhances anaerobic hydrogen production process. Applied Microbiology and Biotechnology, 58 (2), 2002.

22. LEE Y.J., MIYAHARA T., NOIKE T. Effect of iron concentration on hydrogen fermentation. Bioresource Technology, 80 (3), 2001. 
23. OKAMOTO M., MIYAHARA T., MIZUNO O., NOIKE T. Biological hydrogen potential of materials characteristic of the organic fraction of municipal solid wastes. Water Science and Technology: A Journal of the International Association on Water Pollution Research, 41 (3), 2000.

24. GINKEL S. VAN, SUNG S., LAY J.-J. Biohydrogen Production as a Function of $\mathrm{pH}$ and Substrate Concentration. Environmental Science \& Technology, 35 (24), 2001.

25. LOGAN B.E., OH S.-E., KIM I.S., VAN GINKEL S. Biological Hydrogen Production Measured in Batch Anaerobic Respirometers. Environmental Science \& Technology, 36 (11), 2002.

26. UENO Y., HARUTA S., ISHII M., IGARASHI Y. Microbial community in anaerobic hydrogen-producing microflora enriched from sludge compost. Applied Microbiology and Biotechnology, 57 (4), 2001.

27. KAWAGOSHI Y., HINO N., FUJIMOTO A., NAKAO M., FUJITA Y., SUGIMURA S., FURUKAWA K. Effect of inoculum conditioning on hydrogen fermentation and $\mathrm{pH}$ effect on bacterial community relevant to hydrogen production. Journal of Bioscience and Bioengineering, 100 (5), 2005

28. ISMAIL I., HASSAN M.A., ABDUL RAHMAN N.A., SOON C.S. Thermophilic biohydrogen production from palm oil mill effluent (POME) using suspended mixed culture. Biomass and Bioenergy, 34 (1), 2010.
29. LIU Z., LI Q., ZHANG C., WANG L., HAN B., LI B., XING X. Effects of operating parameters on hydrogen production from raw wet steam-exploded cornstalk and two-stage fermentation potential for biohythane production. Biochemical Engineering Journal 90, 2014.

30. KARTHIKEYAN O.P., VISVANATHAN C. Bio-energy recovery from high-solid organic substrates by dry anaerobic bio-conversion processes: a review. Reviews in Environmental Science and Bio/Technology, 12 (3), 2013.

31. TABATABAEI M., ZAKARIA M.R., RAHIM R.A., WRIGHT A.G., SHIRAI Y., ABDULLAH N., HASSAN M.A. PCR-based DGGE and FISH analysis of methanogens in an anaerobic closed digester tank for treating palm oil mill effluent. Electronic Journal of Biotechnology, 12 (3), 2009.

32. PAN J., ZHANG R., ELMASHAD H., SUN H., YING Y. Effect of food to microorganism ratio on biohydrogen production from food waste via anaerobic fermentation. International Journal of Hydrogen Energy, 33 (23), 2008.

33. VALDEZ-VAZQUEZ I., POGGI-VARALDO H. M. Hydrogen production by fermentative consortia. Renewable and Sustainable Energy Reviews, 13 (5), 2009.

34. ALI SHAH F., MAHMOOD Q., MAROOF SHAH M., PERVEZ A., AHMAD ASAD S. Microbial Ecology of Anaerobic Digesters: The Key Players of Anaerobiosis. The Scientific World Journal. 2014, 183752, 2014. 